\title{
Animal Models of Zika Virus Infection during Pregnancy
}

\author{
Elizabeth A. Caine ${ }^{1}$, Brett W. Jagger ${ }^{1}$ and Michael S. Diamond ${ }^{1,2,3,4, *}$ \\ 1 Department of Medicine, Washington University School of Medicine, Saint Louis, MO 63110, USA; \\ ecaine@wustl.edu (E.A.C.); bjagger@wustl.edu (B.W.J.) \\ 2 Department of Pathology \& Immunology, Washington University School of Medicine, \\ Saint Louis, MO 63110, USA \\ 3 Department of Molecular Microbiology, Washington University School of \\ Medicine, Saint Louis, MO 63110, USA \\ 4 The Andrew M. and Jane M. Bursky Center for Human Immunology and Immunotherapy Programs, \\ Washington University School of Medicine, Saint Louis, MO 63110, USA \\ * Correspondence: diamond@wusm.wustl.edu
}

Received: 12 October 2018; Accepted: 30 October 2018; Published: 31 October 2018

check for updates

\begin{abstract}
Zika virus (ZIKV) emerged suddenly in the Americas in 2015 and was associated with a widespread outbreak of microcephaly and other severe congenital abnormalities in infants born to mothers infected during pregnancy. Vertical transmission of ZIKV in humans was confirmed when viral RNA was detected in fetal and placental tissues, and this outcome has been recapitulated experimentally in animals. Unlike other flaviviruses, ZIKV is both arthropod- and sexually-transmitted, and has a broad tissue tropism in humans, including multiple tissues of the reproductive tract. The threats posed by ZIKV have prompted the development of multiple in vivo models to better understand the pathogenesis of ZIKV, particularly during pregnancy. Here, we review the progress on animal models of ZIKV infection during pregnancy. These studies have generated a foundation of insights into the biology of ZIKV, and provide a means for evaluating vaccines and therapeutics.
\end{abstract}

Keywords: Zika virus; vaccines; animal models; pregnancy; non-human primates; mice; congenital Zika syndrome; pathogenesis

\section{Introduction}

Zika virus (ZIKV) is a mosquito-transmitted, positive-sense RNA virus in the Flaviviridae family. ZIKV was first isolated from a rhesus macaque in the Zika Forest of Uganda in 1947 [1]. Historically, human cases were rarely reported, with ZIKV infections being clinically unapparent, causing only mild fever, malaise, and a rash, or being misdiagnosed as Dengue virus infections. However, beginning in 2007 in the Yap Islands of Micronesia [2] and subsequently in 2013 in French Polynesia [3], the epidemiology of ZIKV changed, with higher rates of symptomatic disease, including an association with Guillain-Barré syndrome in adults, and evidence of epidemic transmission [4]. ZIKV emerged in the Western Hemisphere in 2015 and caused epidemics in Central and South America and the Caribbean islands [5]. During its spread throughout the Americas, ZIKV became a public health concern due to its ability to cross the placenta and infect neuroprogenitor cells in the fetal brain, leading to microcephaly, congenital abnormalities, preterm birth, and death [6].

Thousands of infants in the Americas have been born with congenital ZIKV syndrome (CZS), which will impair their future neurodevelopmental function [7]. CZS is defined by severe microcephaly; damage to the eye, including chorioretinal atrophy; and congenital muscular contractures that restrict 
body movement [8]. Although microcephaly has been the hallmark of CZS, many infants exposed to ZIKV in utero are born without this morphological anomaly. However, infants without microcephaly have been diagnosed with epilepsy, hypertonia, and a decreased brain volume [9]. On a microscopic level, ZIKV infected fetuses showed evidence of the altered migration of neuroprogenitor cells, neuronal apoptosis, and lesions in gray matter structures.

A correlation has been seen between the trimester of exposure to ZIKV and fetal outcome. In one study in Brazil, $55 \%$ of first trimester infections resulted in fetal abnormalities compared to only $29 \%$ during the third trimester [6]. In the United States, maternal ZIKV diagnoses during the first, second, or third trimester resulted in $6 \%, 5 \%$, or $4 \%$ rates of ZIKV-associated birth defects, respectively [10]. Another cohort in the United States reported that $11 \%$ of first trimester ZIKV exposures resulted in CZS, whereas no complications were seen in completed pregnancies that were ZIKV exposed in the second and third trimesters [11]. One woman in her 11th week of gestation (first trimester) was diagnosed with persistent viremia (10 weeks after the onset of clinical symptoms) that resulted in fetal brain abnormalities, including decreased neuronal white matter and subventricular zone volume [12]. It remains unclear whether environmental or immunological co-factors have contributed to the higher rates of ZIKV-induced congenital anomalies seen in Brazil compared to other parts of the Americas.

In response to the ZIKV pandemic and the outbreak of congenital disease, animal models were developed to study ZIKV pathogenesis and evaluate countermeasures, including new vaccines and therapies. The ability to control the infection route and gestational age has allowed researchers to confirm the teratogenic effects of ZIKV infection and study both host and viral factors associated with vertical transmission and neuropathogenesis.

\section{Mouse Models}

Mice are the most commonly used animals to model viral infections in humans. Their low cost, short breeding times, large litters, and ease of handling facilitate their widespread use. They often recapitulate important aspects of human disease, including after viral and bacterial infections [13-15]. Mice have also been used widely to evaluate correlates of protection for vaccines and therapeutics before the initiation of clinical studies in human subjects [16,17]. Moreover, the ability to manipulate mice genetically (transgenes, CRISPR-Cas9 mutations, homologous recombination, and conditional deletions) to examine how particular genes influence infection and immunity makes them a preferred animal for many in vivo studies.

In the context of pregnancy, there are advantages and disadvantages for using mice to study human infection and disease. Specific breeding schemes with knockout mice allow for the study of the function of individual genes by restricting their expression to the maternal or fetal side of the placenta. However, mice have a much shorter gestation period compared to humans, only 20 days, and the structure of their placenta differs [18]. Even so, when Brazil saw an increase in microcephaly cases in 2015 associated with the outbreak of ZIKV, the high throughput and availability of mouse infection platforms during pregnancy allowed for the first direct causal link between ZIKV and fetal abnormalities to be established [19].

\subsection{Type I Interferon Receptor Deficient Mouse Models}

Peripheral challenge of adult wild-type (WT) C57BL/6 mice with ZIKV resulted in little virus replication and no disease [20]. One reason for the resistance of WT mice to peripheral infection is that ZIKV fails to antagonize mouse Stat2, a key intermediate in the IFN signaling pathway, whereas it can promote degradation of human STAT2 [21,22]. To dampen the innate immune response and facilitate ZIKV replication in mice, the initial mouse models in the field utilized type I interferon (IFN) receptor knockout mice (Ifnar $1^{-/}$) or administered a blocking anti-type I IFN receptor antibody (MAR1-5A3) (Table 1). For vertical transmission studies, two models were developed: WT C57BL/6 females were crossed to WT C57BL/ 6 sires, and then dams were given the anti-Ifnar1 antibody immediately before ZIKV infection; or Ifnar $1^{-/-}$dams were crossed to WT sires and then inoculated with ZIKV. 
Subcutaneous infections with ZIKV (French Polynesia strain) in these models on embryo day (E)6.5 and harvested seven days later on E13.5 showed the vertical transmission of ZIKV to the placenta and fetal heads [19]. Decreased fetal head and body size and increased resorption rate were seen in fetuses from ZIKV-infected Ifnar $1^{-/-}$dams. Intravaginal inoculation of Ifnar $1^{-/}$dams mated to WT C57BL/ 6 sires at E4.5 and E8.5 also led to fetal resorption and viral replication in the placenta and fetus on E18.5 [23]. Examination of the placenta revealed that ZIKV infected trophoblasts and endothelial cells, which triggered apoptosis, vascular damage, and placental insufficiency. In these infection models, dams sustained severe ZIKV infection, as evidenced by high levels of viral RNA in the serum, spleen, and brain $[19,23]$. 
Table 1. Mouse Models of ZIKV Infection during Pregnancy.

\begin{tabular}{|c|c|c|c|c|c|}
\hline Dam & Sire & ZIKV Strain(s) & Route of Infection(s) & Phenotypes & References \\
\hline C57BL/6 + anti-Ifnar1 Ab & C57BL/6 & H/PF/2013 (Genbank: KJ776791.2) & SC & IUGR & {$[19,24]$} \\
\hline C57BL/6 + anti-Ifnar1 Ab & C57BL/ 6 & $\begin{array}{c}\text { Mouse-adapted Dakar 41525 } \\
\text { (Genbank: MG758786) }\end{array}$ & SC or IVAG & $\begin{array}{l}\text { Placental injury, viral RNA in } \\
\text { placenta/fetal heads }\end{array}$ & [25-27] \\
\hline Ifnar $1^{-/-}$ & C57BL/6 & H/PF/2013 (Genbank: KJ776791.2) & SC & $\begin{array}{l}\text { Fetal resorption, IUGR, pallor, } \\
\text { placental injury }\end{array}$ & [19] \\
\hline Ifnar1 $1^{-/-}$ & C57BL/6 & FSS13025 (Genbank: KU955593) & IVAG & Fetal resorption, IUGR & [23] \\
\hline C57BL/6 & C57BL/6 & FSS13025 (Genbank: KU955593) & IVAG & IUGR & [23] \\
\hline C57BL/6 & C57BL/6 & SZ01 (Genbank: KU866423) & IP/Intra-ventricular & Brain malformations & [28] \\
\hline C57BL/ 6 & C57BL/ 6 & $\begin{array}{l}\text { MEX1-44 or MR-766 } \\
\text { (Genbank: DQ859059) }\end{array}$ & $\begin{array}{l}\text { Lateral ventricle of } \\
\text { fetal brain }\end{array}$ & $\begin{array}{l}\text { Reduced cortical neural } \\
\text { progenitor cells, brain } \\
\text { malformations, microcephaly }\end{array}$ & {$[29,30]$} \\
\hline C57BL/ 6 & C57BL/6 & Brazilian clinical isolate & IV & $\begin{array}{l}\text { No clinical signs in pups, no } \\
\text { virus detected }\end{array}$ & [31] \\
\hline SJL & SJL & Brazilian clinical isolate & IV & $\begin{array}{c}\text { IUGR, brain malformations, } \\
\text { ocular abnormalities }\end{array}$ & {$[31]$} \\
\hline ICR & ICR & SZ01 (Genbank: KU866423) & $\begin{array}{l}\text { Lateral ventricle of fetal } \\
\text { brain }\end{array}$ & $\begin{array}{l}\text { Reduced brain size, brain } \\
\text { malformations }\end{array}$ & {$[32,33]$} \\
\hline $\operatorname{Irf3} 3^{-1-} \operatorname{Irf7} 7^{-/-}$ & $\operatorname{Irf} 3^{-1-} \operatorname{Irff} 7^{-1-}$ & FSS13025 (Genbank: KU955593) & IVAG & IUGR & [23] \\
\hline AG129 & AG129 & $\begin{array}{c}\text { Malaysia P6-740 } \\
\text { (Genbank: KX377336) }\end{array}$ & SC & $\begin{array}{l}\text { Viral RNA in placenta and fetal } \\
\text { heads, reduced weight and } \\
\text { head length }\end{array}$ & [34] \\
\hline C57BL/ 6 & C57BL/ 6 & PRVABC59 (Genbank: KU501215) & IV & $\begin{array}{l}\text { Fetal resorption, little to no viral } \\
\text { RNA in placenta and fetal heads }\end{array}$ & [35] \\
\hline CD1 & CD1 & $\begin{array}{l}\text { FSS13025 (Genbank: KU955593), } \\
\text { Brazil Paraíba } 2015 \text { (Genbank: } \\
\text { KX280026), PRVABC59 (Genbank: } \\
\text { KU501215), } 1968 \text { Nigeria } \\
\text { (Genbank: HQ234500) }\end{array}$ & IU & $\begin{array}{l}\text { Viral RNA in uterine horn, } \\
\text { placenta, fetal head, increase in } \\
\text { number of aborted fetuses }\end{array}$ & [36] \\
\hline
\end{tabular}


Table 1. Cont

\begin{tabular}{|c|c|c|c|c|c|}
\hline Dam & Sire & ZIKV Strain(s) & Route of Infection(s) & Phenotypes & References \\
\hline CD1 & CD1 & 1968 Nigeria (Genbank: HQ234500) & IP & $\begin{array}{l}\text { No viral RNA in placenta or } \\
\text { fetal heads }\end{array}$ & [36] \\
\hline hSTAT2 KI & hSTAT2 KI or C57BL/ 6 & $\begin{array}{c}\text { Mouse-adapted Dakar } 41525 \\
\text { (Genbank: MG758786) and Parent } \\
\text { Dakar } 41525 \text { (Genbank: MG758785) }\end{array}$ & SC & $\begin{array}{l}\text { Viral RNA in placenta and } \\
\text { fetal heads }\end{array}$ & [37] \\
\hline SJL & SJL & PA 259459 & IV & $\begin{array}{l}\text { Viral RNA in fetal heads, } \\
\text { Sofosbuvir protected fetuses }\end{array}$ & {$[38]$} \\
\hline $\mathrm{C} 57 \mathrm{BL} / 6$ or $\mathrm{FVB} / \mathrm{NJ}$ & $\mathrm{C} 57 \mathrm{BL} / 6$ or $\mathrm{FVB} / \mathrm{NJ}$ & $\begin{array}{l}\text { HS-2015-BA-01 (Bahia, Brazil) } \\
\text { (Genbank: KX520666) }\end{array}$ & IV (External jugular) & $\begin{array}{l}\text { Fetal and maternal viral RNA; } \\
\text { fetal pathology including } \\
\text { pericardial edema and abnormal } \\
\text { fore and hind limbs }\end{array}$ & [39] \\
\hline Rag $1^{-/-}+$anti-Ifnar1 $\mathrm{Ab}$ & $\begin{array}{c}\text { Rag1 } 1^{-/-}(+/- \text {anti-Ifnar1 } \\
\mathrm{Ab}\end{array}$ & $\begin{array}{l}\text { Brazil Paraíba 2015 } \\
\text { (Genbank: KX280026) }\end{array}$ & IP & $\begin{array}{c}\text { Vertical transmission, viral RNA } \\
\text { in fetus, placenta, } \\
\text { maternal tissues }\end{array}$ & [40] \\
\hline Ifnar1 $1^{-/-}$ & $\begin{array}{c}\text { Rag1 } 1^{-/-}(+/- \text {anti-Ifnar1 } \\
\mathrm{Ab}\end{array}$ & $\begin{array}{l}\text { Brazil Paraíba 2015 } \\
\text { (Genbank: KX280026) }\end{array}$ & IP & $\begin{array}{l}\text { Sexual transmission } \\
\text { (male-to-female), viral RNA in } \\
\text { placenta and uterus }\end{array}$ & [40] \\
\hline AG129 & AG129 & PRVABC59 (Genbank: KU501215) & SC, IVAG, Sexual & $\begin{array}{l}\text { Infectious ZIKV in maternal } \\
\text { brain, uterus, ovary, and fetus } \\
\text { through all route of infection }\end{array}$ & [41] \\
\hline C57BL/6 & C57BL/6 & SMGC-1 (Genbank: KX266255) & IU (via laparotomy) & $\begin{array}{l}\text { Ocular pathology, microcephaly, } \\
\text { neuronal loss, hind limb } \\
\text { paralysis, spontaneous abortions }\end{array}$ & [42] \\
\hline $\begin{array}{l}\text { Swiss-Webster + } \\
\text { anti-Ifnar1 Ab }\end{array}$ & Swiss-Webster & HN16 (Genbank: KY328289) & SC & $\begin{array}{l}\text { Growth restriction in pups, } \\
\text { decreased brain weight, viral } \\
\text { RNA in brain and spinal cord } \\
\text { of fetuses }\end{array}$ & [43] \\
\hline ICR & ICR & $\begin{array}{l}\text { GZ01 (Genbank: KU820898), } \\
\text { FSS13025 (Genbank: KU955593) }\end{array}$ & $\begin{array}{l}\text { Fetus and pup } \\
\text { intra-ventricular }\end{array}$ & $\begin{array}{l}\text { ZIKV induced microcephaly, loss } \\
\text { of neurons, neutralizing antibody } \\
\text { protected pups } \\
\text { from microcephaly }\end{array}$ & {$[44,45]$} \\
\hline Ifnar $1^{-/-}$ & C57BL/ 6 & $\begin{array}{l}\text { Brazil Paraíba } 2015 \\
\text { (Genbank: KX280026) }\end{array}$ & SC & $\begin{array}{l}\text { Fetal resorption, viral RNA in } \\
\text { fetus and placenta, microcephaly }\end{array}$ & [46] \\
\hline
\end{tabular}


Table 1. Cont.

\begin{tabular}{|c|c|c|c|c|c|}
\hline Dam & Sire & ZIKV Strain(s) & Route of Infection(s) & Phenotypes & References \\
\hline C57BL $/ 6$ & C57BL/ 6 & SZ01 (Genbank: KU866423) & IA & $\begin{array}{l}\text { Decrease in brain volume and } \\
\text { cortical thickness of fetuses, } \\
\text { paralysis and motor function } \\
\text { deficits in pups }\end{array}$ & [47] \\
\hline C57BL/ 6 & C57BL/ 6 & ZIKA-SMGC-1 (Genbank KX266255) & $\mathrm{IU}$ & $\begin{array}{l}\text { Pups developed microcephaly, } \\
\text { ocular defects, paralysis }\end{array}$ & [42] \\
\hline $\begin{array}{l}\text { C57BL/6 }\left(\mathrm{H}-2^{\mathrm{b}}\right)+ \\
\text { anti-Ifnar1 Ab }\end{array}$ & Balb $/ c\left(H-2^{d}\right)$ & $\begin{array}{l}\text { PRVABC59 (Genbank: KU501215) } \\
\text { and MR766 (Genbank: DQ859059) }\end{array}$ & SC & $\begin{array}{l}\text { Viral RNA in fetal tissue and } \\
\text { maternal serum, spleen, liver, } \\
\text { and brain }\end{array}$ & [48] \\
\hline $\mathrm{Balb} / \mathrm{c}+$ anti-Ifnar1 $\mathrm{Ab}$ & $\mathrm{Balb} / \mathrm{c}$ & $\begin{array}{l}\text { GZ01 (Genbank: KU820898) and } \\
\text { FSS13025 (Genbank: KU955593) }\end{array}$ & SC & $\begin{array}{l}\text { Viral RNA in fetal head and } \\
\text { placenta, hemorrhagic uterus }\end{array}$ & [49] \\
\hline $\begin{array}{c}\text { Ifnar1 }^{-/-} \text {Ifngri } 1^{-/-} \\
\text {(AG6) }\end{array}$ & $\begin{array}{c}\text { Ifnar1 }^{-/-} \text {Ifngri } 1^{-/-} \\
\text {(AG6) }\end{array}$ & SZ-WIV01 (KU963796) & IP & In utero death & [50] \\
\hline Ifnar1 $1^{-/-}$ & C57BL/ 6 & $\begin{array}{l}\text { Brazil Paraiba 2015 } \\
\text { (Genbank: KX280026) }\end{array}$ & SC & Fetal resorption & {$[25,26]$} \\
\hline Ifnar1 $1^{-/-}$ & C57BL $/ 6$ & FSS13025 (Genbank: KU955593) & SC or IV & $\begin{array}{l}\text { Fetal resorption, decreased } \\
\text { fetal size }\end{array}$ & [51] \\
\hline C57BL/6 + anti-Ifnar1 Ab & C57BL $/ 6$ & FSS13025 (Genbank: KU955593) & IV & $\begin{array}{c}\text { Viral RNA in fetal tissue, } \\
\text { placenta, maternal serum, brain, } \\
\text { and spleen }\end{array}$ & [51] \\
\hline $\begin{array}{c}\text { Atg161 }{ }^{\mathrm{HM}}+\text { anti-Ifnar1 } \\
\mathrm{Ab}\end{array}$ & $\operatorname{Atg} 161^{\mathrm{HM}}$ & $\begin{array}{l}\text { Brazil Paraiba 2015 } \\
\text { (Genbank: KX280026) }\end{array}$ & SC & $\begin{array}{l}\text { Reduction in viral RNA in } \\
\text { placenta and fetus compared to } \\
\text { WT controls }\end{array}$ & [52] \\
\hline $\begin{array}{l}\text { Cyp } 19 \mathrm{Cre}^{+} \operatorname{Atg} 16 \mathrm{~L} 1^{\mathrm{fl} / \mathrm{fl}}+ \\
\text { anti-Ifnar1 } \mathrm{Ab}\end{array}$ & Cyp $19 \mathrm{Cre}^{+}$Atg16L1 $1^{\mathrm{fl} / \mathrm{fl}}$ & $\begin{array}{l}\text { Brazil Paraiba 2015 } \\
\text { (Genbank: KX280026) }\end{array}$ & SC & $\begin{array}{l}\text { Restricted ZIKV infection in } \\
\text { placenta compared to controls }\end{array}$ & [52] \\
\hline A129 & A129 & PRVABC59 (Genbank: KU501215) & SC & $\begin{array}{l}\text { Viral RNA in placenta, fetal head, } \\
\text { maternal brain, reduced } \\
\text { fetal weight }\end{array}$ & [53] \\
\hline
\end{tabular}

SC = Subcutaneous; IP = Intraperitoneal; IVAG = Intravaginal; IV = Intravenous; IU = Intrauterine; IA = Intraaminotic; IUGR = intrauterine growth restriction. 
The effects of type III IFNs during ZIKV infection have been evaluated in pregnancy using Ifnlr $1^{-/-}$dams crossed to WT C57BL/6 or Ifnlr $1^{-/-}$sires. Ifnlr $1^{-/-}$dams were treated with an anti-Ifnar1 antibody and then inoculated with ZIKV on E12. Whereas Ifnlr1 $1^{-/-} \times I f n l r 1^{-/-}$matings resulted in an increase in viral infection in the placenta and fetal heads, Ifnlr1 ${ }^{-/-}$dam $\times$WT C57BL/6 sire matings had a similar viral burden to WT C57BL/ 6 mice. This data suggested that the feto-placental unit had to be fully deficient in type III IFN signaling [46] to be affected, although an isolated deficiency of Ifnlr1 in the fetuses (obtained through an Ifnlr $1^{+/}$dam $\times$Ifnlr $1^{-/}$sire cross) was not tested. Treatment with pegylated mouse IFN- $\lambda 2$ at E12 but not E6 reduced the ZIKV burden in the placenta and fetal heads late in gestation. Subsequent studies showed that the protective effect of IFN- $\lambda 2$ required a developed placenta, which occurs by E10. These studies established the role of type III IFN signaling in restricting ZIKV infection in the placenta in a gestational stage-dependent manner, and have been corroborated in human tissues [46,54].

\subsection{Immunocompetent Mouse Models}

ZIKV infection in non-pregnant and pregnant immunocompetent C57BL/6, BALB/c, Swiss Webster, or CD-1 mice (via subcutaneous, intraperitoneal, or intravenous routes) resulted in no clinical signs of disease and little viral replication [20,55], presumably because infection was aborted in the setting of intact innate immunity. Nonetheless, closer analysis revealed that some viral replication does happen in these mice, and that in certain circumstances, vertical transmission and accompanying fetal abnormalities can occur. WT C57BL/6 dams inoculated via an intravaginal route with ZIKV shed viral RNA in vaginal washes for six days [23]. Viral particles were reported in the cortex and cerebellum of brains isolated from these fetuses by electron microscopy, even though, paradoxically, viral RNA was not detected by real-time RT-PCR [23]. Intraperitoneal inoculation of pregnant WT C57BL/ 6 dams led to the infection of radial glia cells of the dorsal ventricular zone of the infected fetuses [28]. ZIKV injected directly into the amniotic fluid or uterus of pregnant WT C57BL/6 mice at E13 or E15 resulted in spontaneous abortions, spinal cord defects, and motor neuron and ocular malformations or intracranial calcifications in surviving mice [42,47]. WT SJL mice that were inoculated via an intravenous route with a very high dose of a Brazilian strain of ZIKV developed intrauterine growth restriction (IUGR) and microcephaly [31].

Fetal abnormalities in these WT mouse models were only seen when non-physiological routes of infection were used, including intrauterine, intravenous, or direct injection into the amniotic fluid or uterus. In an effort to create a peripheral challenge model with a more immunocompetent mouse, one group replaced the mouse Stat2 gene with the human STAT2 ortholog (hSTAT2-KI mice) [37]. This substitution allowed ZIKV to antagonize human STAT2 in mice to overcome some of the innate immune restrictions [21]. For these studies, a mouse adapted ZIKV (Dakar strain) with an adaptive amino acid change in the NS4B protein (G18R) was created by passaging in $R a g 1^{-/-}$mice, which lack mature B and T cells [37]. Using a combination of the adapted ZIKV Dakar strain with hSTAT2-KI mice, a model of vertical transmission was demonstrated after subcutaneous infection. High levels of ZIKV RNA were isolated from the placenta and fetal heads of these mice.

\subsection{Effects of Type I IFN Signaling on Fetal Resorption}

In the context of the studies with type I IFN deficiency, it was found that factors other than a viral burden contribute to the fetal outcome. Type I IFN signaling in the placenta was shown to contribute independently to fetal resorption [56]. Ifnar1 ${ }^{-/-}$dams mated to WT C57BL/6 sires yield pups that are heterozygous for Ifnar1 expression. Despite having the ability to respond to type I IFN, these fetuses were not protected from ZIKV, and many were resorbed $[19,23]$. However, when type I IFN signaling was completely deficient in the fetus (by Ifnar $1^{-/} \times$Ifnar1 $^{-/-}$matings), paradoxically, greater survival was observed after intravaginal inoculation on E5.5 than with fetuses that had an intact type I IFN response [56]. Remarkably, the ZIKV burden in the placenta and fetal head was higher in fetuses from Ifnar $1^{-/-} \times$Ifnar $1^{-/-}$than Ifnar $1^{-/-} \times$WT C57BL/ 6 matings, such that the 
viral load did not directly correlate with the outcome. Type I IFN signaling in the placenta was shown to instigate fetal demise and may serve as a way to select against the development of fetuses that have been exposed to and sustained significant viral infections or inflammation. The effect of intact type I IFN signaling on fetal resorption was observed when WT C57BL/6 dams mated with WT C57BL/6 sires were inoculated intravenously with a Puerto Rican strain of ZIKV at E9.5. These fetuses were resorbed at day E17.5, even in the absence of viral RNA in fetal heads [35].

\subsection{Gestational Stage Effects}

More severe fetal abnormalities correlate with the trimester in which a pregnant human is infected with ZIKV [57]. In a large cohort of 301 confirmed ZIKV infections during pregnancy from French Guiana, mothers infected during the first and second trimesters had a greater risk of severe fetal abnormalities, compared to infections during the third trimester [58]. Consistent with this data, pregnant CD1 mice inoculated via intrauterine injection with ZIKV had greater fetal viability and lower viral RNA levels $48 \mathrm{~h}$ later when infected at E14 instead of E10 [36]. Similarly, pregnant C57BL/6 mice inoculated with ZIKV had a greater number of resorbed fetuses five days post infection when they were inoculated at E9.5 compared to E12.5 [35]. Moreover, Ifnar1 ${ }^{-/}$- dams mated to WT C57BL/6 sires had fetuses with reduced head circumferences and crown rump length when infected with ZIKV at E9 but not E12 [46]. Viral burden and the rates of fetal demise were highest in mice infected at E6, compared to E9 and E12. Finally, growth defects were observed in pups of Swiss-Webster dams inoculated with ZIKV at E4 and E8, but not E12 [43].

\subsection{Summary}

Mouse models provided a rapid platform for confirming the teratogenic potential of ZIKV infection. Fetal abnormalities were observed in fetuses from ZIKV infected pregnant Ifnar1 $1^{-/-}$ mice that were mated to WT sires. Viral RNA was isolated from the placentas and fetal heads, with gestational age being a determinant of increased viral burden. Type I IFN was found to be a determinant of fetal resorption after ZIKV infection. Type III IFN- $\lambda$ responses protected the placenta from ZIKV, and dams treated with pegylated IFN- $\lambda 2$ had improved pregnancy outcomes. An immunocompetent hSTAT2-KI model was recently developed and also showed vertical transmission after subcutaneous ZIKV infection. Overall, mice have been used successfully to model many aspects of ZIKV infection during pregnancy and provided a way for establishing correlates of protection for ZIKV countermeasures.

\section{Development of ZIKV Countermeasures in Pregnant Mice}

\subsection{Vaccines}

The epidemic of CZS in the Americas has spurred an accelerated effort by academia, the government, and industry to develop vaccines capable of preventing the potentially devastating consequences of maternal ZIKV exposure for the developing fetus. In the first description of the efficacy of ZIKV immunization against challenge during pregnancy, WT C57BL/6 dams were immunized with either live-attenuated NS1-mutant (LAV) or lipid nanoparticle-encapsulated mRNA (mRNA-LNP) vaccines [24]. Approximately one month after primary immunization or secondary boosting, females were mated with WT C57BL/6 sires. Pregnant dams were treated with an anti-Ifnar1 blocking antibody on E5, followed by subcutaneous challenge with ZIKV on E6. Placental and fetal tissues harvested on E13 revealed wide dissemination of ZIKV in placebo-vaccinated dams, with a high viral burden in the placenta and rates of transmission to fetal heads. In contrast, mice immunized with either the LAV or mRNA-LNP vaccine showed 100,000-fold reductions in placental ZIKV infection, with most free of any detectable ZIKV RNA. The findings in the placenta were recapitulated in the fetal heads, with the majority of both ZIKV vaccine groups showing no evidence of infection. Consistent with these data, fetal viability was markedly greater at term after vaccinating with the 
mRNA-LNP vaccine, whereas resorption and fetal demise were uniformly seen in placebo-immunized mice. A similar WT dam + anti-Ifnar1 antibody model was employed to evaluate a $3^{\prime}$-untranslated region mutant ZIKV LAV. In these studies, maternal serum neutralization titers inversely correlated with placental viral burden, suggesting a humoral correlate of vaccine protection against CZS [27]. The strengths of this challenge model in pregnant mice include the low cost and ease of scalability owing to the use of commercially-procured WT mice and a transient anti-Ifnar1 blockade. However, the anti-Ifnar1 blockade is an imperfect approximation of ZIKV-mediated type I IFN antagonism, since all cells (not just ZIKV-infected cells) are affected. Indeed, despite serum neutralizing antibody titers of 1:10,000 in some vaccinated mice, ZIKV seeded and infected a proportion of placentas after peripheral subcutaneous challenge, and even transmitted the virus to some fetal heads. However, complete protection was seen in the placenta and fetal heads of fetuses from Ifnar1 ${ }^{-/-}$A129 dams that were immunized with a different live attenuated ZIKV vaccine containing deletions in the capsid protein [53].

Subsequent reports of vaccine efficacy in pregnant mice have made modifications that may provide specific advantages. For example, WT C57BL/6 $\left(\mathrm{H}-2^{\mathrm{b}}\right)$ females were primed by prior ZIKV infection and mated to allogeneic, WT BALB/c $\left(\mathrm{H}-2^{\mathrm{d}}\right)$ males [48]. Allogeneic mating was hypothesized to better mimic the typical situation in human pregnancy, where maternal tolerance of paternal antigens modifies the immunologic state of the placenta, in particular, the accumulation of immunosuppressive regulatory $\mathrm{CD}^{+} \mathrm{T}$ cells, to maintain a state of tolerance to the fetus. The dams were given no immunosuppression during priming by ZIKV, and exhibited no signs of illness during this primary infection as a result. However, even this abortive infection was sufficient to protect fetuses after subsequent anti-Ifnar1 antibody treatment and ZIKV challenge during pregnancy (at E10 or E11), as judged by the markedly decreased ZIKV RNA burden in feto-placental units three days after challenge. Consistent with the earlier reports, a sizeable subset of feto-placental units was still positive for ZIKV RNA, despite high titers of circulating neutralizing antibody.

In addition to studying infection and disease in fetuses, some groups have followed pups from vaccinated dams through birth or challenged immediately after birth. ICR female mice were immunized with a recombinant E ectodomain protein (E90: 450 amino acids) vaccine and mated with ICR sires. Pregnant dams were challenged with ZIKV at E13.5 in the cerebral lateral ventricle of the fetal brain. Immunized fetuses inspected five days later were protected from infection and neuroprogenitor cell injury, and neonates from vaccinated dams were protected against microcephaly [44]. The performance of a ZIKV-JEV chimeric LAV (prM-E genes of ZIKV) was evaluated in immunocompetent, four-week-old BALB/c females [49]. Sixty days after immunization, vaccinated dams were challenged at E13 after mating with WT males by intraperitoneal injection. In these experiments, no maternal viremia was detected. In a permutation of this model, one-day-old suckling mice from the vaccinated dams were challenged via intracranial injection. This resulted in universal death of the control pups, but $100 \%$ survival of pups born to ZIKV-JEV LA-immunized dams. This approach offers the theoretical advantage of avoiding exogenous immunosuppression, but at the expense of preventing the assessment of vaccine performance against transplacental transmission. As an alternative to a transient type I IFN blockade, in an experiment with a limited number of animals, females deficient in both type I and II IFN receptor signaling (Ifnar1 ${ }^{-/}$Ifngr $^{-/-}$) were utilized to evaluate a codon pair deoptimized LAV ZIKV vaccine [50]. Pregnant Ifnar1-/- Ifngr1 ${ }^{-/-}$dams were challenged with ZIKV six days after mating to Ifnar1-/- Ifngr $1^{-/}$sires, which resulted in $100 \%$ of unvaccinated dams succumbing prior to delivery, whereas all immunized dams gave birth to healthy-appearing pups. However, no further virological, morphological, or behavioral assessment of the pups was reported.

\subsection{Antibody Treatment}

Studies of human patients have suggested roles for humoral immunity in controlling natural ZIKV infection [59]. Based on this observation, several groups have pursued the identification of strongly 
neutralizing anti-ZIKV antibodies with potential therapeutic application [60]. The highly neutralizing human monoclonal antibody $(\mathrm{mAb})$ ZIKV-117 was evaluated in pregnant mice [26]. Ifnar1 ${ }^{-/}$dams were mated to WT sires, and ZIKV-117 was administered the day prior to ZIKV challenge. Although treatment with an isotype control $\mathrm{mAb}$ resulted in fetal demise and resorption, the vast majority of ZIKV-117-treated fetuses remained morphologically intact at E13. The authors also used the WT dams + anti-Ifnar1 mAb model to show that the passive transfer of ZIKV-117 as prophylaxis or post-exposure therapy resulted in markedly reduced placental and fetal viral burdens, although some tissues remained positive for ZIKV RNA. ZIKV-117 treatment also significantly improved placental and fetal dimensions to levels similar to uninfected animals. Introduction of the L234A/L235A "LALA" mutations, which abrogates Fc-Fc $\gamma \mathrm{R}$ interaction and prevents antibodies from mediating antibody-dependent enhancement, did not alter the efficacy of ZIKV-117 against placental or fetal infection, suggesting that antibody effector functions were not required for the therapeutic efficacy of ZIKV-117.

A similar scheme was utilized to assess the efficacy of the cross-reactive, envelope-dimer epitope (EDE) mAb EDE1-B10 when given to pregnant mice infected with various strains of ZIKV [25]. Ifnar $^{-1-}$ dams were mated to WT sires and challenged subcutaneously on E6 with a Brazilian ZIKV strain, followed by single-dose EDE1-B10 treatment on the day following infection. A nine-fold reduction in the rate of fetal demise was observed in $\mathrm{mAb}$-treated mice, and this correlated with reductions in ZIKV-induced damage to the junctional zone of the placenta. Administration of EDE1-B10 $\mathrm{mAb}$ to WT + anti-Ifnar1 mAb-treated mice one day after maternal infection with a mouse adapted ZIKV (Dakar strain) resulted in a markedly reduced ZIKV burden in the placenta $(660,0000$-fold reduction) and fetal head (4900-fold reduction), with a substantial fraction of placentas and fetal heads containing no detectable virus. Notably, a LALA-mutant of EDE1-B10 performed similarly in the WT + anti-Ifnar1 model. Treatment with EDE1-B10 at a later time point (i.e., three days following infection) in the WT + anti-Ifnar1 model also reduced ZIKV RNA in maternal and fetal tissues, but to a lesser degree, implying that antibody-based therapeutics may need to be administered within a certain time window after infection to convey maximal benefit. This also suggests that antibody-mediated immune clearance of established placental ZIKV infection may be subject to physiologic limitations.

In a separate report, Regla-Nava et al. utilized Ifnar $1^{-/-}$dams mated to WT sires to test the consequences of antecedent DENV infection on secondary ZIKV infection during pregnancy [51]. Fetuses within DENV2-immune dams were noted to maintain a normal size and weight after ZIKV challenge on E7, in contrast to non-immune controls. Anti-CD8 ${ }^{+} \mathrm{T}$ cell depletion abrogated this protective effect of DENV immunity on the fetus. Anti-CD4 ${ }^{+} \mathrm{T}$ cell depletion also increased the fetal resorption rate, but only in a subset of animals. The central role of $\mathrm{CD} 8^{+} \mathrm{T}$ cells in mediating cross-immunity against ZIKV during pregnancy was recapitulated by $\mathrm{CD} 8^{+} \mathrm{T}$ cell depletions in the WT dams + anti-Ifnar1 mAb model and in $C D 8^{-/-}$dams. Thus, for both humoral and cell-mediated mechanisms, murine models have generated evidence for protective mechanisms that can be corroborated in non-human primate models and ultimately, in humans.

\section{Non-human Primate (NHP) Models}

The non-human primate (NHP) model of ZIKV infection in pregnancy shares greater similarities with humans than mice [61,62]. NHPs have comparable placental architecture to humans and longer gestation times (macaques, 146-186 days) than rodents and ruminants [63,64] and have been used extensively to study the infection and treatment of other TORCH (Toxoplasmosis, Other [syphilis, varicella-zoster, HIV, parvovirus B19], Rubella, Cytomegalovirus (CMV), and Herpesvirus infections) pathogens [65-69]. Among NHPs, macaques (Macaca) have been used most frequently for the study of ZIKV pathogenesis during pregnancy (Table 2). The first infection models of pregnancy were generated in pigtail (Macaca nemestrina) and rhesus (Macaca mulatta) macaques with isolates of ZIKV from French Polynesia, Cambodia, Brazil, and Puerto Rico. Vertical transmission of ZIKV was reported, although fetal abnormalities and brain injury were relatively minor [70-72]. However, more recent 
ZIKV infection studies on pregnant rhesus macaques have demonstrated significant fetal demise using primary isolates from Brazil, as well as larger groups of infected animals [73].

\subsection{Maternal Syndrome in NHPS}

Most ZIKV-infected pregnant pigtail and rhesus macaque dams appeared healthy, which is analogous to the asymptomatic or mildly symptomatic infections of humans [74]. Minor clinical signs were reported that lasted through the first week of infection. In several rhesus and pigtail macaques, maternal tissues at term (brains, spleens, eyes, kidney, liver, lymph node, saliva, and decidua) were positive for ZIKV RNA [70,72]. One consistent observation was the presence of ZIKV RNA in urine in many rhesus macaque dams for up to two weeks after infection [71,72]. Longitudinal sampling studies revealed persistent viral RNA in the serum and plasma in a subset of pregnant NHPs, which has also been reported during human pregnancies [12]. ZIKV RNA was present in the plasma/sera of both pigtail and rhesus macaques for 11 to 70 days post infection, with peak viremia observed within the first week [71-73,75,76]. One study observed that NHPs infected with ZIKV Brazil in the first trimester exhibited longer periods of sustained viremia (28 to 70 days) then those inoculated during the second trimester (14-42 days) [75]. Common marmosets (Callithrix jacchus) infected with ZIKV also had prolonged viremia and viruria [77], which correlated with the spread to fetal and maternal tissues. These observations are notable since persistent viremia was not observed in non-pregnant NHPs, even though immune responses were similar, including the level of neutralizing antibodies [72]. The infected fetus and/or placenta has been hypothesized to act as a reservoir that cannot be efficiently cleared by the immune response and contribute to the persistent maternal ZIKV viremia observed during pregnancy; however, more studies are needed to test this hypothesis.

The paucity of clinical signs observed in infected NHP dams correlates with the observation that many ZIKV infections in humans are asymptomatic. Although most human studies in pregnant women have focused on symptomatic cases, the frequency of CZS in asymptomatic cases may be similar, making fetal demise and miscarriages from ZIKV infection more common than initially thought [78]. Among a cohort of ZIKV infections in the United States, birth defects were present in 5 and $4 \%$ of women who were symptomatic and asymptomatic, respectively [10]. This observation was recapitulated in NHPs when a combined analysis of all ZIKV pregnancy NHP studies revealed that fetal abnormalities and CZS were observed in NHP dams showing few, if any, clinical signs of disease [79]. Together, observations in NHPs and humans indicate that fetal abnormalities caused by ZIKV infection can occur regardless of maternal symptoms.

\subsection{Fetal Infection and CZS in NHPs}

Although many of the initial NHP studies reported few maternal clinical signs, ZIKV crossed the placental barrier and reached the fetus, resulting in minor brain abnormalities (Table 2). ZIKV RNA was detected in different fetal organs of rhesus and pigtail macaques, including the brain, lymph node, pericardium, and lung [72,73]. Magnetic resonance imaging scans in pigtail macaques inoculated with ZIKV showed that periventricular lesions developed in the occipital-parietal lobes of fetal brains 10 days after infection [70]. Injury to the ependyma with underlying gliosis in the posterior lateral ventricles and apoptosis of neuroprogenitor cells was also observed in the brains of infected pigtail and rhesus macaques $[75,80]$. This was consistent with previous studies in mice and humans showing that ZIKV infects and causes the abnormal proliferation and migration of neuroprogenitor cells [19, 31,81-83]. When ZIKV was directly inoculated into the amniotic fluid of rhesus macaque fetuses at gestational day (GD) 50, GD64, or GD90, all fetuses exhibited periventricular and subventricular loss of neural precursors near term [84].

Infection studies in pregnant NHPs have also shown that exposure to ZIKV at earlier gestational times results in more severe outcomes for the fetus. The percentage of fetal death in utero was higher in rhesus macaques inoculated in the first trimester with a Brazilian ZIKV isolate, whereas second and third trimester infections survived to term [73]. Pregnant rhesus macaques infected with a French 
Polynesian ZIKV strain during the first but not third trimester resulted in fetuses that developed inflammatory ocular pathology in the retina, choroid, and optic nerve [72].

CZS was observed in NHPs when fetuses from rhesus macaque dams were inoculated with ZIKV early during gestation ( $<7$ weeks). Fetuses infected early in pregnancy showed a reduction in occipitofrontal diameter and head circumference at term compared to non-infected NHPs, but no gross microcephaly was observed. However, these fetuses showed evidence of microcalcifications, hemorrhage, and neuronal necrosis. Fetuses that were exposed to ZIKV earlier in pregnancy also developed more severe spinal cord, ocular, and neuromuscular pathology. In comparison, fetuses exposed to ZIKV at a later time point (>12 weeks) sustained fewer neuropathologic lesions [75].

Fetal demise was also seen in NHPs infected with ZIKV. Pregnant common marmosets inoculated with a Brazilian ZIKV isolate transmitted the virus to their fetuses, which developed neuropathology and early demise [77]. In a meta-analysis of ZIKV infected pregnant NHPs at six National Primate Research Centers, fetal death was observed in 13 of 50 animals (26.0\%) and early neonatal death in three animals [79]. No fetal or neonatal death was observed in macaques inoculated after GD55, whereas macaques inoculated on or before the first trimester had a rate of fetal demise of $37.8 \%$. All cases of fetal death occurred in dams that had prolonged viremia. ZIKV RNA was detected in the amniotic and chorionic fluid, placenta, and fetus at the time of demise in most pigtail and rhesus macaques and marmosets $[73,77,80]$.

The placenta was a target of ZIKV infection in rhesus macaques with significant pathology observed, including chorioamnionitis and deciduitis that resulted in damage to the placental villi $[72,85,86]$. Damage to the placenta could increase the chances of fetal abnormalities or demise following ZIKV infection. This includes a lack of oxygen transport across the villi to the fetus, as well as an increase in maternal cellular infiltration and increase in Hofbauer cells (placental macrophages) that can damage the villous architecture and alter the placenta immunological barrier $[86,87]$. It is also hypothesized that ZIKV may use Hofbauer cells as one of its initial targets of infection, which could enhance transmission to the fetus [87]. 
Table 2. Non-Human Primate Models of ZIKV Infection during Pregnancy.

\begin{tabular}{|c|c|c|c|c|c|c|c|}
\hline Model & ZIKV Strain & Route & Dose & Time Infected & $\begin{array}{l}\text { Number NHPs } \\
\text { Infected }\end{array}$ & Phenotypes & References \\
\hline Rhesus macaque & $\begin{array}{l}\text { H/PF/2013 } \\
\text { (GenBank: } \\
\text { KJ776791.2) }\end{array}$ & SC & $10^{4} \mathrm{PFU}$ & GD: 31 or 38 & 2 & Persistent viremia & [71] \\
\hline Rhesus macaque & $\begin{array}{l}\text { H/PF/2013 } \\
\text { (GenBank: } \\
\text { KJ776791.2) }\end{array}$ & SC & $10^{4} \mathrm{PFU}$ & $\begin{array}{c}\text { GD: } 31,38,104, \text { or } \\
199\end{array}$ & 4 & Persistent viremia, viral RNA in fetus & {$[72]$} \\
\hline Rhesus macaque & $\begin{array}{l}\text { PRVABC59 } \\
\text { (Genbank: } \\
\text { KU501215.1) }\end{array}$ & SC & $10^{5} \mathrm{FFU}$ & $\begin{array}{c}\text { GD: } 31,51,114 \text {, or } \\
115\end{array}$ & 5 & $\begin{array}{l}\text { Viral RNA in fetus, placenta damage, decreased } \\
\text { oxygen permeability, villous calcification, } \\
\text { stromal proliferation, fibrin deposition, subtle } \\
\text { fetal brain abnormalities in } 2 \text { of } 5 \text { animals } \\
\text { (second and third trimester) }\end{array}$ & [86] \\
\hline Rhesus macaque & $\begin{array}{l}\text { Brazil ZKV2015 } \\
\text { (GenBank: } \\
\text { KU497555.1) }\end{array}$ & SC & $10^{3} \mathrm{PFU}$ & GD: $42-98$ & 9 & $\begin{array}{l}\text { Persistent viremia, fetal neuropathology, fetal } \\
\text { loss, smaller brain size, brain lesions, apoptosis } \\
\text { of neuroprogenitor cells, placental pathology }\end{array}$ & [75] \\
\hline Rhesus macaque & $\begin{array}{l}\text { PRVABC59 } \\
\text { (Genbank: } \\
\text { KU501215.1)-Barcoded }\end{array}$ & SC & $10^{4} \mathrm{PFU}$ & GD: 35 & 1 & Persistent viremia & {$[76]$} \\
\hline Rhesus macaque & $\begin{array}{l}\text { Rio U-1/2016 } \\
\text { (Genbank: } \\
\text { KU926309) }\end{array}$ & SC & $10^{4} \mathrm{PFU}$ & GD: $44-124$ & 11 & $\begin{array}{l}\text { Virus in the amniotic fluid (AF); and in utero } \\
\text { fetal deaths }\end{array}$ & [73] \\
\hline Rhesus macaque & $\begin{array}{l}\text { Brazil SPH2015 } \\
\text { (GenBank: } \\
\text { KU321639.1 }\end{array}$ & IA & $10^{5} \mathrm{PFU}$ & $\begin{array}{l}\text { GD: } 41,50,64, \text { or } \\
90\end{array}$ & 4 & $\begin{array}{l}\text { Fetal demise, high viral RNA levels in fetal and } \\
\text { placental tissues, including brain; fetuses carried } \\
\text { to near term and euthanized displayed no gross } \\
\text { microcephaly, but had brain calcifications and } \\
\text { reduced neural precursor cells }\end{array}$ & [84] \\
\hline Pigtail macaque & $\begin{array}{l}\text { Cambodia } \\
\text { FSS13025 } \\
\text { (GenBank: } \\
\text { KU955593.1) }\end{array}$ & SC & $5 \times 10^{7} \mathrm{PFU}$ & GD: 119 & 1 & $\begin{array}{l}\text { Ultrasound lag in growth biparietal diameter, } \\
\text { fetal brain lesions, viral RNA in fetal brain, liver, } \\
\text { placenta }\end{array}$ & [70] \\
\hline
\end{tabular}


Table 2. Cont.

\begin{tabular}{|c|c|c|c|c|c|c|c|}
\hline Model & ZIKV Strain & Route & Dose & Time Infected & $\begin{array}{l}\text { Number NHPs } \\
\text { Infected }\end{array}$ & Phenotypes & References \\
\hline Pigtail macaque & $\begin{array}{c}\text { Cambodia } \\
\text { FSS13025 } \\
\text { (GenBank: } \\
\text { KU955593.1) }\end{array}$ & SC & $5 \times 10^{7} \mathrm{PFU}$ & GD: 82 or $119^{3}$ & 2 & $\begin{array}{l}\text { Ependymal injury in posterior lateral ventricles, } \\
\text { fused ventricular surfaces, periventricular } \\
\text { gliosis, white matter GFAP+ gliosis, axonal } \\
\text { spheroids, deficient fetal neuronal progenitor } \\
\text { cells, loss of non-cortical volume in fetal brain } \\
\text { (silent pathology) }\end{array}$ & [80] \\
\hline Pigtail macaque & $\begin{array}{c}\text { Brazil Fortaleza } \\
2015 \text { (GenBank: } \\
\text { KX811222.1) }\end{array}$ & $\mathrm{SC}^{1}$ & $5 \times 10^{7} \mathrm{PFU}$ & GD: $60-63$ & 3 & $\begin{array}{l}\text { Ependymal injury in posterior lateral ventricles, } \\
\text { fused ventricular surfaces, periventricular } \\
\text { gliosis, white matter GFAP+ gliosis, axonal } \\
\text { spheroids, deficient fetal neuronal progenitor } \\
\text { cells, loss of non-cortical volume in fetal brain } \\
\text { (silent pathology) }\end{array}$ & [80] \\
\hline Marmoset & $\begin{array}{l}\text { Brazil SPH2015 } \\
\text { (GenBank: } \\
\text { KU321639.1) }\end{array}$ & $\mathrm{IM}^{2}$ & $2.5 \times 10^{5} \mathrm{PFU}$ & GD: 68 or 79 & 2 & $\begin{array}{l}\text { Fetal demise, abortion, viral RNA in placenta } \\
\text { and fetus }\end{array}$ & [77] \\
\hline
\end{tabular}

$\mathrm{SC}=$ Subcutaneous; $^{\mathrm{IA}}=$ Intraamniotic; $\mathrm{IM}=$ Intramuscular; GD: Gestational day. ${ }^{1}$ Saliva
days later. ${ }^{3} 119$ gestation NHP was same one in 2016 Adams Waldorf et al. publication. 


\subsection{Countermeasure Studies in NHPS}

The NHP model shares many aspects of human ZIKV disease during pregnancy and is important because human efficacy trials for vaccines and therapeutics may be challenging due to the waning of cases in endemic regions. NHP vaccine studies during pregnancy also are important, as highlighted by one study that showed efficacy in mice against vertical transmission, but not in pregnant rhesus macaques [27].

In the sole study to date of an antibody-based therapeutic against ZIKV infection in pregnant NHPs, a cocktail of three LALA mutant anti-ZIKV monoclonal antibodies (SMZAb1, SMZAb2, SMZAb5) was given to pregnant rhesus macaques intravenously three days post infection, at the time of peak viremia [73]. Pregnant animals were inoculated subcutaneously with a Brazilian ZIKV isolate during the third trimester (GD: 106, 125, or 134). Although viremia was controlled in two of three macaques, the virus reached the amniotic fluid in one of the animals even though viremia was controlled. In comparison, this antibody cocktail controlled viremia in non-pregnant animals, albeit when administered one day before challenge with ZIKV [88]. The authors concluded that $\mathrm{mAb}$ treatment following ZIKV infection in pregnant subjects is unlikely to prevent transfer of the virus to the fetus.

\section{Other Models}

Whereas mice and NHPs are most commonly used to study ZIKV infection during pregnancy, chicken eggs and pigs also have been utilized to assess the link to fetal abnormalities. Embryonated chicken eggs were used to evaluate ZIKV infection in developing embryos. Eggs injected through the amniotic membrane into the inner member space with ZIKV at E2 or E5.5 resulted in malformed chick brains [89]. High dose infections resulted in embryo loss, and ZIKV RNA was isolated from the brain, eyes, liver, heart, and crop intestine of chicken embryos.

Domestic pigs have been used to study human viral infections. Pigs have similar anatomy, genetics, and physiology to humans, although their placental structures differ [90]. Pregnant domestic pigs were inoculated with ZIKV in utero, either via intracerebral or intraperitoneal + intraaminotic routes at GD50. Viral RNA was detected in the placenta and amniotic fluid, and piglets were smaller in size at birth and developed seizures and paralysis [91]. In a separate study, ZIKV was unable to cross the porcine placenta after infection through a subcutaneous route, even though the placenta became infected when direct in utero infection was performed [92]. When the placenta was bypassed, similar results in piglets were seen, including ZIKV infection of the brain, depletion of neurons in the cerebral cortex, and microcephaly in a subset of cases.

\section{Conclusions}

In just a few years following the ZIKV outbreak in the Americas, animal models have been developed and used to study the detrimental effects of ZIKV on the developing fetus. These models have confirmed vertical transmission, the teratogenicity of ZIKV, and the ability to cause CZS. Animal models have also provided a platform for testing therapeutics and vaccines against ZIKV during pregnancy. Both NHPs and mice have shown vertical transmission after ZIKV infection, with viral RNA present in the placenta and fetal head. Fetal abnormalities that mimic CZS in humans and damage to neuroprogenitor cells have been observed in both models as well. ZIKV infection in mice and NHPs has confirmed the increased incidence of severe outcomes when infection occurs at early gestational stages. Overall, these models recapitulate many of the phenotypes seen during ZIKV infection of pregnant humans.

Despite the many advances in the field, key questions remain that these models may help to answer: (a) what is the basis for persistent viremia during pregnancy in macaques and humans?; (b) what is the role and cell type specificity of type I IFN signaling on fetal resorption?; (c) what are the long term effects of asymptomatic versus symptomatic infection during pregnancy on the mother 
(e.g., fertility) and children (e.g., neurodevelopmental sequelae)?; and (d) what is the significance of breakthrough infection of the fetus and placenta after vaccination? The marked waning of human infections over the past year is likely to make it challenging to perform human clinical trials and obtain new clinical specimens. Thus, small and large animal models of ZIKV infection during pregnancy will continue to have utility in addressing these and other questions, as the threat of ZIKV outbreaks and associated CZS is likely to remain in endemic regions for the foreseeable future.

Funding: This work was supported by grants from the NIH (R01 AI073755, R01 AI127828, and R01 HD091218) to M.S.D. B.W.J. was supported by an NIH training grant award (T32 AI007172).

Conflicts of Interest: M.S.D. is a consultant for Inbios and Sanofi-Pasteur and is on the Scientific Advisory Board of Moderna.

\section{References}

1. Dick, G.W.; Kitchen, S.F.; Haddow, A.J. Zika virus. I. Isolations and serological specificity. Trans. R. Soc. Trop. Med. Hyg. 1952, 46, 509-520. [CrossRef]

2. Duffy, M.R.; Chen, T.H.; Hancock, W.T.; Powers, A.M.; Kool, J.L.; Lanciotti, R.S.; Pretrick, M.; Marfel, M.; Holzbauer, S.; Dubray, C.; et al. Zika virus outbreak on Yap Island, Federated States of Micronesia. N. Engl. J. Med. 2009, 360, 2536-2543. [CrossRef] [PubMed]

3. Cao-Lormeau, V.M.; Roche, C.; Teissier, A.; Robin, E.; Berry, A.L.; Mallet, H.P.; Sall, A.A.; Musso, D. Zika virus, French polynesia, South pacific, 2013. Emerg. Infect. Dis. 2014, 20, 1085-1086. [CrossRef] [PubMed]

4. Cao-Lormeau, V.M.; Blake, A.; Mons, S.; Lastere, S.; Roche, C.; Vanhomwegen, J.; Dub, T.; Baudouin, L.; Teissier, A.; Larre, P.; et al. Guillain-Barre Syndrome outbreak associated with Zika virus infection in French Polynesia: A case-control study. Lancet 2016, 387, 1531-1539. [CrossRef]

5. Hennessey, M.; Fischer, M.; Staples, J.E. Zika Virus Spreads to New Areas-Region of the Americas, May 2015-January 2016. Morb. Mortal. Wkly. Rep. 2016, 65, 55-58. [CrossRef] [PubMed]

6. Brasil, P.; Pereira, J.P., Jr.; Moreira, M.E.; Ribeiro Nogueira, R.M.; Damasceno, L.; Wakimoto, M.; Rabello, R.S.; Valderramos, S.G.; Halai, U.A.; Salles, T.S.; et al. Zika Virus Infection in Pregnant Women in Rio de Janeiro. N. Engl. J. Med. 2016, 375, 2321-2334. [CrossRef] [PubMed]

7. Delaney, A.; Mai, C.; Smoots, A.; Cragan, J.; Ellington, S.; Langlois, P.; Breidenbach, R.; Fornoff, J.; Dunn, J.; Yazdy, M.; et al. Population-Based Surveillance of Birth Defects Potentially Related to Zika Virus Infection-15 States and U.S. Territories, 2016. Morb. Mortal. Wkly. Rep. 2018, 67, 91-96. [CrossRef] [PubMed]

8. Moore, C.A.; Staples, J.E.; Dobyns, W.B.; Pessoa, A.; Ventura, C.V.; Fonseca, E.B.; Ribeiro, E.M.; Ventura, L.O.; Neto, N.N.; Arena, J.F.; et al. Characterizing the Pattern of Anomalies in Congenital Zika Syndrome for Pediatric Clinicians. JAMA Pediatr. 2017, 171, 288-295. [CrossRef] [PubMed]

9. Van der Linden, V.; Pessoa, A.; Dobyns, W.; Barkovich, A.J.; Junior, H.V.; Filho, E.L.; Ribeiro, E.M.; Leal, M.C.; Coimbra, P.P.; Aragao, M.F.; et al. Description of 13 Infants Born During October 2015-January 2016 With Congenital Zika Virus Infection Without Microcephaly at Birth-Brazil. Morb. Mortal. Wkly. Rep. 2016, 65, 1343-1348. [CrossRef] [PubMed]

10. Shapiro-Mendoza, C.K.; Rice, M.E.; Galang, R.R.; Fulton, A.C.; VanMaldeghem, K.; Prado, M.V.; Ellis, E.; Anesi, M.S.; Simeone, R.M.; Petersen, E.E.; et al. Pregnancy Outcomes After Maternal Zika Virus Infection During Pregnancy-U.S. Territories, January 1, 2016-April 25, 2017. Morb. Mortal. Wkly. Rep. 2017, 66, 615-621. [CrossRef] [PubMed]

11. Honein, M.A.; Dawson, A.L.; Petersen, E.E.; Jones, A.M.; Lee, E.H.; Yazdy, M.M.; Ahmad, N.; Macdonald, J.; Evert, N.; Bingham, A.; et al. Birth Defects Among Fetuses and Infants of US Women With Evidence of Possible Zika Virus Infection During Pregnancy. JAMA 2017, 317, 59-68. [CrossRef] [PubMed]

12. Driggers, R.W.; Ho, C.Y.; Korhonen, E.M.; Kuivanen, S.; Jaaskelainen, A.J.; Smura, T.; Rosenberg, A.; Hill, D.A.; DeBiasi, R.L.; Vezina, G.; et al. Zika Virus Infection with Prolonged Maternal Viremia and Fetal Brain Abnormalities. N. Engl. J. Med. 2016, 374, 2142-2151. [CrossRef] [PubMed]

13. McGruder, B.; Saxena, V.; Wang, T. Lessons from the Murine Models of West Nile Virus Infection. Methods Mol. Biol. 2016, 1435, 61-69. [PubMed] 
14. Wang, Z.; Wang, S.S.; Wang, G.L.; Wu, T.L.; Lv, Y.L.; Wu, Q.M. A pregnant mouse model for the vertical transmission of Brucella melitensis. Vet. J. 2014, 200, 116-121. [CrossRef] [PubMed]

15. Takaki, H.; Oshiumi, H.; Shingai, M.; Matsumoto, M.; Seya, T. Development of mouse models for analysis of human virus infections. Microbiol. Immunol. 2017, 61, 107-113. [CrossRef] [PubMed]

16. Wang, L.; Liu, J.; Kong, Y.; Hou, L.; Li, Y. Immunogenicity of Recombinant Adenovirus Type 5 Vector-Based Ebola Vaccine Expressing Glycoprotein from the 2014 Epidemic Strain in Mice. Hum. Gene Ther. 2018, 29, 87-95. [CrossRef] [PubMed]

17. Fuchs, J.; Chu, H.; O’Day, P.; Pyles, R.; Bourne, N.; Das, S.C.; Milligan, G.N.; Barrett, A.D.; Partidos, C.D.; Osorio, J.E. Investigating the efficacy of monovalent and tetravalent dengue vaccine formulations against DENV-4 challenge in AG129 mice. Vaccine 2014, 32, 6537-6543. [CrossRef] [PubMed]

18. Coyne, C.B.; Lazear, H.M. Zika virus-Reigniting the TORCH. Nat. Rev. Microbiol. 2016, 14, 707-715. [CrossRef] [PubMed]

19. Miner, J.J.; Cao, B.; Govero, J.; Smith, A.M.; Fernandez, E.; Cabrera, O.H.; Garber, C.; Noll, M.; Klein, R.S.; Noguchi, K.K.; et al. Zika Virus Infection during Pregnancy in Mice Causes Placental Damage and Fetal Demise. Cell 2016, 165, 1081-1091. [CrossRef] [PubMed]

20. Lazear, H.M.; Govero, J.; Smith, A.M.; Platt, D.J.; Fernandez, E.; Miner, J.J.; Diamond, M.S. A Mouse Model of Zika Virus Pathogenesis. Cell Host Microbe 2016, 19, 720-730. [CrossRef] [PubMed]

21. Grant, A.; Ponia, S.S.; Tripathi, S.; Balasubramaniam, V.; Miorin, L.; Sourisseau, M.; Schwarz, M.C.; Sanchez-Seco, M.P.; Evans, M.J.; Best, S.M.; et al. Zika Virus Targets Human STAT2 to Inhibit Type I Interferon Signaling. Cell Host Microbe 2016, 19, 882-890. [CrossRef] [PubMed]

22. Kumar, A.; Hou, S.; Airo, A.M.; Limonta, D.; Mancinelli, V.; Branton, W.; Power, C.; Hobman, T.C. Zika virus inhibits type-I interferon production and downstream signaling. EMBO Rep. 2016, 17, 1766-1775. [CrossRef] [PubMed]

23. Yockey, L.J.; Varela, L.; Rakib, T.; Khoury-Hanold, W.; Fink, S.L.; Stutz, B.; Szigeti-Buck, K.; Van den Pol, A.; Lindenbach, B.D.; Horvath, T.L.; et al. Vaginal Exposure to Zika Virus during Pregnancy Leads to Fetal Brain Infection. Cell 2016, 166, 1247-1256.e4. [CrossRef] [PubMed]

24. Richner, J.M.; Himansu, S.; Dowd, K.A.; Butler, S.L.; Salazar, V.; Fox, J.M.; Julander, J.G.; Tang, W.W.; Shresta, S.; Pierson, T.C.; et al. Modified mRNA Vaccines Protect against Zika Virus Infection. Cell 2017, 168, 1114-1125.e10. [CrossRef] [PubMed]

25. Fernandez, E.; Dejnirattisai, W.; Cao, B.; Scheaffer, S.M.; Supasa, P.; Wongwiwat, W.; Esakky, P.; Drury, A.; Mongkolsapaya, J.; Moley, K.H.; et al. Human antibodies to the dengue virus E-dimer epitope have therapeutic activity against Zika virus infection. Nat. Immunol. 2017, 18, 1261-1269. [CrossRef] [PubMed]

26. Sapparapu, G.; Fernandez, E.; Kose, N.; Bin, C.; Fox, J.M.; Bombardi, R.G.; Zhao, H.; Nelson, C.A.; Bryan, A.L.; Barnes, T.; et al. Neutralizing human antibodies prevent Zika virus replication and fetal disease in mice. Nature 2016, 540, 443-447. [CrossRef] [PubMed]

27. Shan, C.; Muruato, A.E.; Jagger, B.W.; Richner, J.; Nunes, B.T.D.; Medeiros, D.B.A.; Xie, X.; Nunes, J.G.C.; Morabito, K.M.; Kong, W.P.; et al. A single-dose live-attenuated vaccine prevents Zika virus pregnancy transmission and testis damage. Nat. Commun. 2017, 8, 676. [CrossRef] [PubMed]

28. Wu, K.Y.; Zuo, G.L.; Li, X.F.; Ye, Q.; Deng, Y.Q.; Huang, X.Y.; Cao, W.C.; Qin, C.F.; Luo, Z.G. Vertical transmission of Zika virus targeting the radial glial cells affects cortex development of offspring mice. Cell Res. 2016, 26, 645-654. [CrossRef] [PubMed]

29. Shao, Q.; Herrlinger, S.; Yang, S.L.; Lai, F.; Moore, J.M.; Brindley, M.A.; Chen, J.F. Zika virus infection disrupts neurovascular development and results in postnatal microcephaly with brain damage. Development 2016, 143, 4127-4136. [CrossRef] [PubMed]

30. Shao, Q.; Herrlinger, S.; Zhu, Y.N.; Yang, M.; Goodfellow, F.; Stice, S.L.; Qi, X.P.; Brindley, M.A.; Chen, J.F. The African Zika virus MR-766 is more virulent and causes more severe brain damage than current Asian lineage and dengue virus. Development 2017, 144, 4114-4124. [CrossRef] [PubMed]

31. Cugola, F.R.; Fernandes, I.R.; Russo, F.B.; Freitas, B.C.; Dias, J.L.; Guimaraes, K.P.; Benazzato, C.; Almeida, N.; Pignatari, G.C.; Romero, S.; et al. The Brazilian Zika virus strain causes birth defects in experimental models. Nature 2016, 534, 267-271. [CrossRef] [PubMed]

32. Wang, S.; Hong, S.; Deng, Y.Q.; Ye, Q.; Zhao, L.Z.; Zhang, F.C.; Qin, C.F.; Xu, Z. Transfer of convalescent serum to pregnant mice prevents Zika virus infection and microcephaly in offspring. Cell Res. 2017, 27, 158-160. [CrossRef] [PubMed] 
33. Li, C.; Xu, D.; Ye, Q.; Hong, S.; Jiang, Y.; Liu, X.; Zhang, N.; Shi, L.; Qin, C.F.; Xu, Z. Zika Virus Disrupts Neural Progenitor Development and Leads to Microcephaly in Mice. Cell Stem Cell 2016, 19, 672. [CrossRef] [PubMed]

34. Julander, J.G.; Siddharthan, V.; Park, A.H.; Preston, E.; Mathur, P.; Bertolio, M.; Wang, H.; Zukor, K.; Van Wettere, A.J.; Sinex, D.G.; et al. Consequences of in utero exposure to Zika virus in offspring of AG129 mice. Sci. Rep. 2018, 8, 9384. [CrossRef] [PubMed]

35. Szaba, F.M.; Tighe, M.; Kummer, L.W.; Lanzer, K.G.; Ward, J.M.; Lanthier, P.; Kim, I.J.; Kuki, A.; Blackman, M.A.; Thomas, S.J.; et al. Zika virus infection in immunocompetent pregnant mice causes fetal damage and placental pathology in the absence of fetal infection. PLoS Pathog. 2018, 14, e1006994. [CrossRef] [PubMed]

36. Vermillion, M.S.; Lei, J.; Shabi, Y.; Baxter, V.K.; Crilly, N.P.; McLane, M.; Griffin, D.E.; Pekosz, A.; Klein, S.L.; Burd, I. Intrauterine Zika virus infection of pregnant immunocompetent mice models transplacental transmission and adverse perinatal outcomes. Nat. Commun. 2017, 8, 14575. [CrossRef] [PubMed]

37. Gorman, M.J.; Caine, E.A.; Zaitsev, K.; Begley, M.C.; Weger-Lucarelli, J.; Uccellini, M.B.; Tripathi, S.; Morrison, J.; Yount, B.L.; Dinnon, K.H., 3rd; et al. An Immunocompetent Mouse Model of Zika Virus Infection. Cell Host Microbe 2018, 23, 672-685. [CrossRef] [PubMed]

38. Mesci, P.; Macia, A.; Moore, S.M.; Shiryaev, S.A.; Pinto, A.; Huang, C.T.; Tejwani, L.; Fernandes, I.R.; Suarez, N.A.; Kolar, M.J.; et al. Blocking Zika virus vertical transmission. Sci. Rep. 2018, 8, 1218. [CrossRef] [PubMed]

39. Xavier-Neto, J.; Carvalho, M.; Pascoalino, B.D.; Cardoso, A.C.; Costa, A.M.; Pereira, A.H.; Santos, L.N.; Saito, A.; Marques, R.E.; Smetana, J.H.; et al. Hydrocephalus and arthrogryposis in an immunocompetent mouse model of ZIKA teratogeny: A developmental study. PLoS Negl. Trop. Dis. 2017, 11, e0005363. [CrossRef] [PubMed]

40. Winkler, C.W.; Woods, T.A.; Rosenke, R.; Scott, D.P.; Best, S.M.; Peterson, K.E. Sexual and Vertical Transmission of Zika Virus in anti-interferon receptor-treated Rag1-deficient mice. Sci. Rep. 2017, 7, 7176. [CrossRef] [PubMed]

41. Duggal, N.K.; McDonald, E.M.; Ritter, J.M.; Brault, A.C. Sexual transmission of Zika virus enhances in utero transmission in a mouse model. Sci. Rep. 2018, 8, 4510. [CrossRef] [PubMed]

42. Shi, Y.; Li, S.; Wu, Q.; Sun, L.; Zhang, J.; Pan, N.; Wang, Q.; Bi, Y.; An, J.; Lu, X.; et al. Vertical Transmission of the Zika Virus Causes Neurological Disorders in Mouse Offspring. Sci. Rep. 2018, 8, 3541. [CrossRef] [PubMed]

43. Valentine, G.C.; Seferovic, M.D.; Fowler, S.W.; Major, A.M.; Gorchakov, R.; Berry, R.; Swennes, A.G.; Murray, K.O.; Suter, M.A.; Aagaard, K.M. Timing of gestational exposure to Zika virus is associated with postnatal growth restriction in a murine model. Am. J. Obstet. Gynecol. 2018, 219, 403.e1-403.e9. [CrossRef] [PubMed]

44. Zhu, X.; Li, C.; Afridi, S.K.; Zu, S.; Xu, J.W.; Quanquin, N.; Yang, H.; Cheng, G.; Xu, Z. E90 subunit vaccine protects mice from Zika virus infection and microcephaly. Acta Neuropathol. Commun. 2018, 6, 77. [CrossRef] [PubMed]

45. Li, C.; Gao, F.; Yu, L.; Wang, R.; Jiang, Y.; Shi, X.; Yin, C.; Tang, X.; Zhang, F.; Xu, Z.; et al. A Single Injection of Human Neutralizing Antibody Protects against Zika Virus Infection and Microcephaly in Developing Mouse Embryos. Cell Rep. 2018, 23, 1424-1434. [CrossRef] [PubMed]

46. Jagger, B.W.; Miner, J.J.; Cao, B.; Arora, N.; Smith, A.M.; Kovacs, A.; Mysorekar, I.U.; Coyne, C.B.; Diamond, M.S. Gestational Stage and IFN-lambda Signaling Regulate ZIKV Infection In Utero. Cell Host Microbe 2017, 22, 366-376. [CrossRef] [PubMed]

47. Cui, L.; Zou, P.; Chen, E.; Yao, H.; Zheng, H.; Wang, Q.; Zhu, J.N.; Jiang, S.; Lu, L.; Zhang, J. Visual and Motor Deficits in Grown-up Mice with Congenital Zika Virus Infection. EBioMedicine 2017, 20, 193-201. [CrossRef] [PubMed]

48. Turner, L.H.; Kinder, J.M.; Wilburn, A.; D’Mello, R.J.; Braunlin, M.R.; Jiang, T.T.; Pham, G.; Way, S.S. Preconceptual Zika virus asymptomatic infection protects against secondary prenatal infection. PLoS Pathog. 2017, 13, e1006684. [CrossRef] [PubMed]

49. Li, X.F.; Dong, H.L.; Wang, H.J.; Huang, X.Y.; Qiu, Y.F.; Ji, X.; Ye, Q.; Li, C.; Liu, Y.; Deng, Y.Q.; et al. Development of a chimeric Zika vaccine using a licensed live-attenuated flavivirus vaccine as backbone. Nat. Commun. 2018, 9, 673. [CrossRef] [PubMed] 
50. Li, P.; Ke, X.; Wang, T.; Tan, Z.; Luo, D.; Miao, Y.; Sun, J.; Zhang, Y.; Liu, Y.; Hu, Q.; et al. Zika Virus Attenuation by Codon Pair Deoptimization Induces Sterilizing Immunity in Mouse Models. J. Virol. 2018, 92. [CrossRef] [PubMed]

51. Regla-Nava, J.A.; Elong Ngono, A.; Viramontes, K.M.; Huynh, A.T.; Wang, Y.T.; Nguyen, A.T.; Salgado, R.; Mamidi, A.; Kim, K.; Diamond, M.S.; et al. Cross-reactive Dengue virus-specific CD8(+) T cells protect against Zika virus during pregnancy. Nat. Commun. 2018, 9, 3042. [CrossRef] [PubMed]

52. Cao, B.; Parnell, L.A.; Diamond, M.S.; Mysorekar, I.U. Inhibition of autophagy limits vertical transmission of Zika virus in pregnant mice. J. Exp. Med. 2017, 214, 2303-2313. [CrossRef] [PubMed]

53. Xie, X.; Kum, D.B.; Xia, H.; Luo, H.; Shan, C.; Zou, J.; Muruato, A.E.; Medeiros, D.B.A.; Nunes, B.T.D.; Dallmeier, K.; et al. A Single-Dose Live-Attenuated Zika Virus Vaccine with Controlled Infection Rounds that Protects against Vertical Transmission. Cell Host Microbe 2018, 24, 487-499. [CrossRef] [PubMed]

54. Bayer, A.; Lennemann, N.J.; Ouyang, Y.; Bramley, J.C.; Morosky, S.; Marques, E.T., Jr.; Cherry, S.; Sadovsky, Y.; Coyne, C.B. Type III Interferons Produced by Human Placental Trophoblasts Confer Protection against Zika Virus Infection. Cell Host Microbe 2016, 19, 705-712. [CrossRef] [PubMed]

55. Rossi, S.L.; Tesh, R.B.; Azar, S.R.; Muruato, A.E.; Hanley, K.A.; Auguste, A.J.; Langsjoen, R.M.; Paessler, S.; Vasilakis, N.; Weaver, S.C. Characterization of a Novel Murine Model to Study Zika Virus. Am. J. Trop. Med. Hyg. 2016, 94, 1362-1369. [CrossRef] [PubMed]

56. Yockey, L.J.; Jurado, K.A.; Arora, N.; Millet, A.; Rakib, T.; Milano, K.M.; Hastings, A.K.; Fikrig, E.; Kong, Y.; Horvath, T.L.; et al. Type I interferons instigate fetal demise after Zika virus infection. Sci. Immunol. 2018, 3. [CrossRef] [PubMed]

57. Lin, H.Z.; Tambyah, P.A.; Yong, E.L.; Biswas, A.; Chan, S.Y. A review of Zika virus infections in pregnancy and implications for antenatal care in Singapore. Singapore Med. J. 2017, 58, 171-178. [CrossRef] [PubMed]

58. Pomar, L.; Malinger, G.; Benoist, G.; Carles, G.; Ville, Y.; Rousset, D.; Hcini, N.; Pomar, C.; Jolivet, A.; Lambert, V. Association between Zika virus and fetopathy: A prospective cohort study in French Guiana. Ultrasound Obstet. Gynecol. 2017, 49, 729-736. [CrossRef] [PubMed]

59. Lai, L.; Rouphael, N.; Xu, Y.; Natrajan, M.S.; Beck, A.; Hart, M.; Feldhammer, M.; Feldpausch, A.; Hill, C.; Wu, H.; et al. Innate, T-, and B-Cell Responses in Acute Human Zika Patients. Clin. Infect. Dis. 2018, 66, 1-10. [CrossRef] [PubMed]

60. Fernandez, E.; Diamond, M.S. Vaccination strategies against Zika virus. Curr. Opin. Virol. 2017, $23,59-67$. [CrossRef] [PubMed]

61. Slayden, O.D. Cyclic remodeling of the nonhuman primate endometrium: A model for understanding endometrial receptivity. Semin. Reprod. Med. 2014, 32, 385-391. [CrossRef] [PubMed]

62. Stouffer, R.L.; Woodruff, T.K. Nonhuman Primates: A Vital Model for Basic and Applied Research on Female Reproduction, Prenatal Development, and Women's Health. ILAR J. 2017, 58, 281-294. [CrossRef] [PubMed]

63. Grigsby, P.L. Animal Models to Study Placental Development and Function throughout Normal and Dysfunctional Human Pregnancy. Semin. Reprod. Med. 2016, 34, 11-16. [CrossRef] [PubMed]

64. Newman, C.; Friedrich, T.C.; O'Connor, D.H. Macaque monkeys in Zika virus research: 1947-present. Curr. Opin. Virol. 2017, 25, 34-40. [CrossRef] [PubMed]

65. Schoondermark-van de Ven, E.M.; Melchers, W.J.; Galama, J.M.; Meuwissen, J.H.; Eskes, T.K. Prenatal diagnosis and treatment of congenital Toxoplasma gondii infections: An experimental study in rhesus monkeys. Eur. J. Obstet. Gynecol. Reprod. Biol. 1997, 74, 183-188. [CrossRef]

66. Tarantal, A.F.; Salamat, M.S.; Britt, W.J.; Luciw, P.A.; Hendrickx, A.G.; Barry, P.A. Neuropathogenesis induced by rhesus cytomegalovirus in fetal rhesus monkeys (Macaca mulatta). J. Infect. Dis. 1998, 177, 446-450. [CrossRef] [PubMed]

67. Adams Waldorf, K.M.; Rubens, C.E.; Gravett, M.G. Use of nonhuman primate models to investigate mechanisms of infection-associated preterm birth. BJOG 2011, 118, 136-144. [CrossRef] [PubMed]

68. Poirier, M.C.; Gibbons, A.T.; Rugeles, M.T.; Andre-Schmutz, I.; Blanche, S. Fetal consequences of maternal antiretroviral nucleoside reverse transcriptase inhibitor use in human and nonhuman primate pregnancy. Curr. Opin. Pediatr. 2015, 27, 233-239. [CrossRef] [PubMed]

69. Smith, M.A.; Takeuchi, K.; Anderson, G.; Ware, G.O.; McClure, H.M.; Raybourne, R.B.; Mytle, N.; Doyle, M.P. Dose-response model for Listeria monocytogenes-induced stillbirths in nonhuman primates. Infect. Immun. 2008, 76, 726-731. [CrossRef] [PubMed] 
70. Adams Waldorf, K.M.; Stencel-Baerenwald, J.E.; Kapur, R.P.; Studholme, C.; Boldenow, E.; Vornhagen, J.; Baldessari, A.; Dighe, M.K.; Thiel, J.; Merillat, S.; et al. Fetal brain lesions after subcutaneous inoculation of Zika virus in a pregnant nonhuman primate. Nat. Med. 2016, 22, 1256-1259. [CrossRef] [PubMed]

71. Dudley, D.M.; Aliota, M.T.; Mohr, E.L.; Weiler, A.M.; Lehrer-Brey, G.; Weisgrau, K.L.; Mohns, M.S.; Breitbach, M.E.; Rasheed, M.N.; Newman, C.M.; et al. A rhesus macaque model of Asian-lineage Zika virus infection. Nat. Commun. 2016, 7, 12204. [CrossRef] [PubMed]

72. Nguyen, S.M.; Antony, K.M.; Dudley, D.M.; Kohn, S.; Simmons, H.A.; Wolfe, B.; Salamat, M.S.; Teixeira, L.B.C.; Wiepz, G.J.; Thoong, T.H.; et al. Highly efficient maternal-fetal Zika virus transmission in pregnant rhesus macaques. PLoS Pathog. 2017, 13, e1006378. [CrossRef] [PubMed]

73. Magnani, D.M.; Rogers, T.F.; Maness, N.J.; Grubaugh, N.D.; Beutler, N.; Bailey, V.K.; Gonzalez-Nieto, L.; Gutman, M.J.; Pedreno-Lopez, N.; Kwal, J.M.; et al. Fetal demise and failed antibody therapy during Zika virus infection of pregnant macaques. Nat. Commun. 2018, 9, 1624. [CrossRef] [PubMed]

74. Haby, M.M.; Pinart, M.; Elias, V.; Reveiz, L. Prevalence of asymptomatic Zika virus infection: A systematic review. Bull. World Health Organ. 2018, 96, 402-413. [CrossRef] [PubMed]

75. Martinot, A.J.; Abbink, P.; Afacan, O.; Prohl, A.K.; Bronson, R.; Hecht, J.L.; Borducchi, E.N.; Larocca, R.A.; Peterson, R.L.; Rinaldi, W.; et al. Fetal Neuropathology in Zika Virus-Infected Pregnant Female Rhesus Monkeys. Cell 2018, 173, 1111-1122. [CrossRef] [PubMed]

76. Aliota, M.T.; Dudley, D.M.; Newman, C.M.; Weger-Lucarelli, J.; Stewart, L.M.; Koenig, M.R.; Breitbach, M.E.; Weiler, A.M.; Semler, M.R.; Barry, G.L.; et al. Molecularly barcoded Zika virus libraries to probe in vivo evolutionary dynamics. PLoS Pathog. 2018, 14, e1006964. [CrossRef] [PubMed]

77. Seferovic, M.; Martin, C.S.; Tardif, S.D.; Rutherford, J.; Castro, E.C.C.; Li, T.; Hodara, V.L.; Parodi, L.M.; Giavedoni, L.; Layne-Colon, D.; et al. Experimental Zika Virus Infection in the Pregnant Common Marmoset Induces Spontaneous Fetal Loss and Neurodevelopmental Abnormalities. Sci. Rep. 2018, 8, 6851. [CrossRef] [PubMed]

78. Paixao, E.S.; Leong, W.Y.; Rodrigues, L.C.; Wilder-Smith, A. Asymptomatic Prenatal Zika Virus Infection and Congenital Zika Syndrome. Open Forum Infect. Dis. 2018, 5, ofy073. [CrossRef] [PubMed]

79. Dudley, D.M.; Van Rompay, K.K.; Coffey, L.L.; Ardeshir, A.; Keesler, R.I.; Bliss-Moreau, E.; Grigsby, P.L.; Steinbach, R.J.; Hirsch, A.J.; MacAllister, R.P.; et al. Miscarriage and stillbirth following maternal Zika virus infection in nonhuman primates. Nat. Med. 2018. [CrossRef] [PubMed]

80. Adams Waldorf, K.M.; Nelson, B.R.; Stencel-Baerenwald, J.E.; Studholme, C.; Kapur, R.P.; Armistead, B.; Walker, C.L.; Merillat, S.; Vornhagen, J.; Tisoncik-Go, J.; et al. Congenital Zika virus infection as a silent pathology with loss of neurogenic output in the fetal brain. Nat. Med. 2018, 24, 368-374. [CrossRef] [PubMed]

81. Chimelli, L.; Melo, A.S.O.; Avvad-Portari, E.; Wiley, C.A.; Camacho, A.H.S.; Lopes, V.S.; Machado, H.N.; Andrade, C.V.; Dock, D.C.A.; Moreira, M.E.; et al. The spectrum of neuropathological changes associated with congenital Zika virus infection. Acta Neuropathol. 2017, 133, 983-999. [CrossRef] [PubMed]

82. Tang, H.; Hammack, C.; Ogden, S.C.; Wen, Z.; Qian, X.; Li, Y.; Yao, B.; Shin, J.; Zhang, F.; Lee, E.M.; et al. Zika Virus Infects Human Cortical Neural Progenitors and Attenuates Their Growth. Cell Stem Cell 2016, 18, 587-590. [CrossRef] [PubMed]

83. Oh, Y.; Zhang, F.; Wang, Y.; Lee, E.M.; Choi, I.Y.; Lim, H.; Mirakhori, F.; Li, R.; Huang, L.; Xu, T.; et al. Zika virus directly infects peripheral neurons and induces cell death. Nat. Neurosci. 2017, 20, 1209-1212. [CrossRef] [PubMed]

84. Coffey, L.L.; Keesler, R.I.; Pesavento, P.A.; Woolard, K.; Singapuri, A.; Watanabe, J.; Cruzen, C.; Christe, K.L.; Usachenko, J.; Yee, J.; et al. Intraamniotic Zika virus inoculation of pregnant rhesus macaques produces fetal neurologic disease. Nat. Commun. 2018, 9, 2414. [CrossRef] [PubMed]

85. Mohr, E.L.; Block, L.N.; Newman, C.M.; Stewart, L.M.; Koenig, M.; Semler, M.; Breitbach, M.E.; Teixeira, L.B.C.; Zeng, X.; Weiler, A.M.; et al. Ocular and uteroplacental pathology in a macaque pregnancy with congenital Zika virus infection. PLoS ONE 2018, 13, e0190617. [CrossRef] [PubMed]

86. Hirsch, A.J.; Roberts, V.H.J.; Grigsby, P.L.; Haese, N.; Schabel, M.C.; Wang, X.; Lo, J.O.; Liu, Z.; Kroenke, C.D.; Smith, J.L.; et al. Zika virus infection in pregnant rhesus macaques causes placental dysfunction and immunopathology. Nat. Commun. 2018, 9, 263. [CrossRef] [PubMed]

87. Noronha, L.; Zanluca, C.; Azevedo, M.L.; Luz, K.G.; Santos, C.N. Zika virus damages the human placental barrier and presents marked fetal neurotropism. Mem. Inst. Oswaldo Cruz 2016, 111, 287-293. [CrossRef] [PubMed] 
88. Magnani, D.M.; Rogers, T.F.; Beutler, N.; Ricciardi, M.J.; Bailey, V.K.; Gonzalez-Nieto, L.; Briney, B.; Sok, D.; Le, K.; Strubel, A.; et al. Neutralizing human monoclonal antibodies prevent Zika virus infection in macaques. Sci. Transl. Med. 2017, 9. [CrossRef] [PubMed]

89. Goodfellow, F.T.; Tesla, B.; Simchick, G.; Zhao, Q.; Hodge, T.; Brindley, M.A.; Stice, S.L. Zika Virus Induced Mortality and Microcephaly in Chicken Embryos. Stem Cells Dev. 2016, 25, 1691-1697. [CrossRef] [PubMed]

90. Meurens, F.; Summerfield, A.; Nauwynck, H.; Saif, L.; Gerdts, V. The pig: A model for human infectious diseases. Trends Microbiol. 2012, 20, 50-57. [CrossRef] [PubMed]

91. Darbellay, J.; Cox, B.; Lai, K.; Delgado-Ortega, M.; Wheler, C.; Wilson, D.; Walker, S.; Starrak, G.; Hockley, D.; Huang, Y.; et al. Zika Virus Causes Persistent Infection in Porcine Conceptuses and may Impair Health in Offspring. EBioMedicine 2017, 25, 73-86. [CrossRef] [PubMed]

92. Wichgers Schreur, P.J.; van Keulen, L.; Anjema, D.; Kant, J.; Kortekaas, J. Microencephaly in fetal piglets following in utero inoculation of Zika virus. Emerg. Microbes Infect. 2018, 7, 42. [CrossRef] [PubMed]

C 2018 by the authors. Licensee MDPI, Basel, Switzerland. This article is an open access article distributed under the terms and conditions of the Creative Commons Attribution (CC BY) license (http:/ / creativecommons.org/licenses/by/4.0/). 